DOI: 10.20472/EFC.2018.010.017

MAtGORZATA KOŁODZIEJCZAK

Poznań University of Life Sciences, Faculty of Economics and Social Sciences, Poland

\title{
THE COST OF SERVICES USE IN HORTICULTURE ON FARMS IN THE EUROPEAN UNION COUNTRIES IN 2004-2016
}

\begin{abstract}
:
Agricultural services address the demand for the technological, economical and environmental dimension of agricultural activities. This paper focuses on agricultural services used by farms specializing in horticultural production. The objective of the study was to identify the output of agricultural services used by farms specializing in horticultural production in European Union countries in 2004-2016. The study was based on a deductive and comparative method and relied on FADN data; also used were correlation indexes. In the group of farms covered by this study, the use of agricultural services may be found to depend on two basic factors. The first one is the farms' development level and the intensity and structure of production activities. The differences between EU-12 and EU-7 countries suggest that national specificities of horticultural production and local farming patterns are at least as important as the development level. Another significant factor is the availability of the farms' own machinery and the amount of labour engaged in production. However, own equipment and service use were not found to be substitutes, whereas companies with large resources of productive inputs usually incurred higher service costs. Also, as the demand for labour grows, so does the demand for services. This suggests that services are complementary rather than substitute to physical capital.
\end{abstract}

\section{Keywords:}

agriculture services, service intensity rate, horticulture, European Union, FADN

JEL Classification: L89, Q16 


\section{Introduction}

The relevant literature often emphasizes the relationship between service development and economic development and advancement. Today, the gradual development of the service sector is quite commonly believed to be a regular economic process such that as the economy develops, agriculture becomes less and less important; the role of industry grows, stabilizes and then declines; and the importance of services keeps increasing. These transformations are accompanied by a reallocation of productive inputs which is reflected in the fact that they are generally absorbed sequentially by the three spheres of activity identified above (Kowalczyk 1983, Bell 1989, Corsten 1990, Daszkowska 1998, Häussermann, Siebel 2011, Jensen 2011, Flejterski, Klóska, Majchrzak 2012, Hamm 2012). The specific impact of these patterns may also be observed inside each sector which supplements its potential with production services in the production processes (in the industrial and agricultural sectors, and inside the service sector, too). This is because economic operators rely on various services not only in their ancillary activities; it is common for them to include services in their core production activity.

Manufacturing services support the rationalization of production processes. Tapping into the service providers' potential and knowledge is a way to reduce the costs of building and maintaining the producers' own potential, to improve the production performance and to enhance product quality. Services also drive progress and promote access to knowledge on manufacturing organization and technologies. When it comes to agriculture, services address the demand for the technological, economical and environmental dimension of activities. Their role and importance have evolved over time. Initially, they were needed in order to close the technological gap. Afterwards, their purpose was to improve the rationality of farming, and to streamline and align the farming activities with the standards applicable in the European Union and with sustainable agriculture assumptions (Kołodziejczak 2016).

This paper focuses on agricultural services related to horticultural crop production. The objective of the study was to identify the output of agricultural services used by farms specializing in horticultural crops ${ }^{1}$ in European Union ${ }^{2}$ countries in 2004-2016. The paper attempts to answer the question: What are the dependencies between selected characteristics of agriculture in individual countries under the study and the level of cost of services use.

\footnotetext{
1 "Horticultural crops" refer to farms specialized in horticultural crops (vegetables, strawberries, flowers and ornamental plants), mushroom production and plant nursery. It does not include agricultural holdings specializing in either tree, berry plant and olive growing (classified as "permanent crops") or in winegrowing (classified as "vineyards").

2 This study does not include Malta and Cyprus (due to marginal importance of local agriculture), Austria, Ireland, Luxembourg, Slovakia and Slovenia (due to lack of farms specializing in horticultural crops) and Croatia and Latvia (due to lack of a complete dataset for the period considered).
} 


\section{Material and methods}

In the paper, service output is defined as the cost of agricultural services incurred by the farms. Agricultural services, i.e. services related to crop production, are defined in accordance with EU law (Regulation (EC) No. 138/2004) as "the hire of machines and equipment with the corresponding labour"1. In this paper, only the services used in horticultural activity are covered by the analysis.

The following was examined: level of and changes in service costs per farm; share of service costs in total material and monetary costs of production; service cost per hectare of agricultural land (AL) and per annual work unit (AWU) ${ }^{2}$; and service intensity ${ }^{3}$ of crop production. The analysis was performed for selected farm characteristics in different countries, taking the following into account: own (FWU $)^{4}$ and hired $(\mathrm{AWU})^{5}$ labour inputs; area of agricultural land; area of leased land, value of machinery, equipment and vehicles; gross value added; and agricultural production structure in different countries. Also used were the following efficiency indexes ${ }^{6}$ : land productivity ${ }^{7}$ and labour productivity 8 (see Józwiak 1998; Poczta 1994). Due to size limitations of this paper, this data could not be presented. However, the strength of correlation between productivity indexes and service output in old EU (EU-12) countries and countries who accessed the EU in or after 2004 (EU-7) was presented.

The analysis was based on a deductive method and correlation analysis (panel correlation) $)^{9}$. This study relied on data collected and processed under the European Union's Farm Accountancy Data Network (FADN). The years covered are 2004-2016, i.e. the EU membership period of countries who joined the EU in or after 2004.

\section{Results of the study}

Table 1 presents the service cost and service intensity of crop production in farm specializing in horticultural crops in EU countries in 2004 and 2016, at 2016 constant

\footnotetext{
${ }^{1}$ Later, the Regulation defined veterinary services as "medicines which are invoiced separately from the veterinary surgeon's fee and veterinary costs which include medicines administered directly by the veterinary surgeon and are recorded with his fee."

${ }^{2}$ AWU (Annual Work Unit) means the total amount of own and hired labor (SE010), i.e. 2120 hours of work within a year (265 working days, 8 hours each).

${ }^{3}$ Measured as service cost per EUR 1,000 worth of crop production.

${ }^{4}$ FWU (Family Work Unit): labor input of the farmer and his/her family, expressed as the number of full-time family employees (own labor inputs) (SE015).

${ }^{5}$ Hired labor expressed in annual work units (FTEs) (SE020).

Cf. Karwat-Woźniak (2008).

${ }^{6}$ Cf. Karwat-Woźniak (2008).

${ }^{7}$ Measured as total production (SE131) per hectare of AL (EUR) (SE025).

${ }^{8}$ Measured as total production (SE131) per AWU (EUR) (SE010).

9 These are commonly known methods, so they do not require a detailed description.
} 
prices. It seems that EU-12 farms spend more on services, generate much more value added and have better access to machinery and equipment than their EU-7 counterparts. However, both groups are internally heterogeneous in that respect, which is mainly due to differences in average farm area, labour inputs and particularities of horticultural production. In the period under consideration, both groups of countries experienced an increase in average service costs per farm, per AWU and per hectare of AL. However, this was not true for all countries included in the groups. The possible reason for a relatively constant share of service costs in intermediate consumption in EU-12 and EU-7

Table 1. The cost of services use, its share in intermediate consumption and service intensity in crop production based on farms specialized in horticulture in the EU countries in 2004 and 2016, at 2016 constant prices

\begin{tabular}{|c|c|c|c|c|c|c|c|c|c|c|}
\hline \multirow[t]{2}{*}{ Countries } & \multicolumn{2}{|c|}{$\begin{array}{l}\text { Agricultural } \\
\text { services per } \\
\text { farm (EUR) }\end{array}$} & \multicolumn{2}{|c|}{$\begin{array}{l}\text { Agricultural } \\
\text { services per } \\
\text { ha of } \\
\text { agricultural } \\
\text { land (EUR) }\end{array}$} & \multicolumn{2}{|c|}{$\begin{array}{c}\text { Agricultural } \\
\text { services per } \\
\text { AWU (EUR) }\end{array}$} & \multicolumn{2}{|c|}{$\begin{array}{c}\text { Share of } \\
\text { agricultural } \\
\text { services in } \\
\text { total } \\
\text { intermediate } \\
\text { consumption } \\
(\%)\end{array}$} & \multicolumn{2}{|c|}{$\begin{array}{c}\text { Service } \\
\text { intensity rate } \\
\text { (agricultural } \\
\text { services per } \\
\text { EUR/1,000 } \\
\text { worth of crop } \\
\text { production) }\end{array}$} \\
\hline & 2004 & 2016 & 2004 & 016 & 2004 & 2016 & 2004 & 2016 & 2004 & 2016 \\
\hline Belg & & & 75 & 912 & 14 & 97 & 3,3 & 3,9 & 16,8 & 20,9 \\
\hline Denr & 9 & & 568 & 558 & 14 & & 2,5 & 2 & 13,7 & 12,2 \\
\hline Finla & & & & 978 & & & 2,1 & & 14,5 & 33,0 \\
\hline Fran & 6 & & 7 & 924 & 15 & 2 & 4,7 & 5 & 26,4 & 29,1 \\
\hline Germany & 26 & I & 504 & 437 & 6 & 658 & 1,6 & 1 , & 10,8 & 9,7 \\
\hline Gre€ & & & 2 & 5 & & 6 & 3 , & 0 & 10,7 & 2,9 \\
\hline al & & & 1 & 84 & & 175 & 0,8 & & 3,2 & 3,4 \\
\hline Neth & 23911 & 39966 & 3159 & 543 & 4232 & 5394 & 6,8 & 7,0 & 37,7 & 40,9 \\
\hline Portu & & 795 & 28 & 172 & 5 & 408 & 0,6 & 4,3 & 2,8 & 20,1 \\
\hline Spain & 2041 & 2343 & 276 & 316 & 689 & 407 & 5,6 & 4,5 & 15,3 & 14,8 \\
\hline Sweder & 35107 & 22966 & 3501 & 4168 & 68 & 5699 & 8,3 & 7,3 & 57,4 & 42,9 \\
\hline Unit & 69 & 8 & 519 & 565 & & 821 & 1,8 & 2,1 & 10,2 & 12,3 \\
\hline $\mathrm{EU}-12$ in & 8002 & 10490 & 1031 & 038 & 1888 & 1946 & 4,2 & 4, & 24,0 & 23,3 \\
\hline Bulga & & & 1 & 71 & 254 & 155 & 4,5 & 3 & 0,8 & 18,2 \\
\hline Czech Re & 9015 & 10599 & 460 & 2697 & 2141 & 2299 & 12,1 & 9,5 & 80,3 & 61,7 \\
\hline Estonia & 2807 & & 15 & 207 & 584 & 1389 & 4,0 & 7,9 & 31,3 & 58,1 \\
\hline Hun & 1014 & 1764 & 195 & 255 & 481 & 726 & 4,3 & 4,3 & 23,8 & 25,3 \\
\hline Lithu & 200 & 254 & 15 & 19 & 55 & 121 & 1,5 & 1,4 & 5,1 & 6,0 \\
\hline & 706 & 950 & 183 & 167 & 245 & 322 & 2,5 & 3,0 & 12,9 & 15,3 \\
\hline Romania $^{a}$ & 966 & 192 & 552 & 181 & 329 & 152 & 7,4 & 5,6 & 30,3 & 22,0 \\
\hline EU-7 in av & 2216 & 2321 & 241 & 373 & 654 & 936 & 6,4 & 6,7 & 39,2 & 39,4 \\
\hline
\end{tabular}

a2004 - data from 2007; b2004 - data from 2005

Source: Own study based on FADN Database (2018) 
countries is that employment went down while demand for agricultural services remained relatively stable (within the UE-12 and UE-7 aggregates). The average increase in service costs per farm in EU-12 and EU-7 was EUR 2,500 and EUR 100, respectively. As regards EU-12, all countries contributed to the general increase, except for Greece, Italy and Sweden. In EU-7, the situation was more complex. A large increase was reported in Czech Republic and Hungary (by EUR 1,600 and EUR 800, respectively); Poland and Lithuania experienced a slight increase; and a decline was recorded in other countries. The agricultural service cost per hectare of $A L$ (Table 1) also varied across the countries but remained relatively stable within the EU-12 aggregate and increased by more than $50 \%$ in EU-7. In EU-12 and EU-7 countries, the average increase in agricultural service cost per AWU was EUR 100 and EUR 300, respectively. Within EU-12, a decrease was recorded in Greece, Spain, Sweden, UK and (to a moderate extent) in Denmark and Italy. Within EU-7, Bulgaria and Romania reported a decline. There was a noticeable increase in the share of services in intermediate consumption within EU-7 (by 0.3 percentage points, on average). In that group, Estonia and Poland were the only ones to experience growth. On average, that index did not change inside the EU-12 group; this was mainly due to a large increase in Finland and Portugal. In turn, a decline was recorded in four countries only.

In EU-12, the service intensity of crop production decreased by EUR 0.7 per EUR 1,000 worth of crop production, on average; in EU-7, it increased by EUR 0.2, on average (Table 1). However, each group was clearly heterogeneous. In EU-12, the largest drop was recorded in Sweden (which could be the consequence of the highest service intensity level in 2004 of all countries considered), followed by Greece, Denmark, Germany and Spain. Other countries, primarily Finland and Portugal, witnessed an increase. In three EU-7 countries, the index declined, the most in Czech Republic and Bulgaria, and in Romania, too. Conversely, the largest increase was recorded in Estonia.

Both in EU-12 and EU-7 countries, the increase in all variables under consideration was accompanied by a growth in service value per farm (Table 2, Table 3). This is especially true for: machinery and equipment value and service cost per AWU; in EU-12: service cost per hectare of AL, service intensity of crop production, land and labor productivity; in EU-7: gross value added and additional area of leased agricultural land. As regards service cost per hectare of $\mathrm{AL}$, the strongest positive correlation was recorded for land productivity (in EU-7 countries) and for service value per farm, service cost per AWU, service intensity of crop production and land productivity (in EU-12 countries). In both aggregates, a slightly weaker relation was observed for the share of service in intermediate consumption, labour productivity and gross value added. As regards additional area of leased agricultural land, a weak negative correlation existed in EU-12, and was close to zero (did not exist) in EU-7. Although horticultural holdings made their choice between using services and hiring employees, the positive correlation between expenditure and service cost per AWU suggests that services are complementary, rather 
than substitute, to employment. This is indirectly confirmed by the positive correlation between service cost per AWU and labour productivity. Therefore, as the demand for labor grew, so did the demand for services. In both aggregates, the increase in service cost per AWU was accompanied, first of all, by an increase in service cost per farm and in service intensity of crop production; in EU-12: by an increase in service costs per hectare of $A L$, in the share of services in intermediate consumption and in land and labour productivity; in EU-7: by an increase in the additional area of leased agricultural land. An increase in the value of machinery and equipment and in gross value added was also reported. As regards the share of service costs in intermediate consumption, the strongest positive relation was observed for service intensity of crop production and (in EU-12) for service costs per hectare of AL and per AWU. A weaker yet positive correlation existed for the service cost per farm in both aggregates; and (in EU-7) for the service cost per hectare of $\mathrm{AL}$ and per $\mathrm{AWU}$, and for the additional area of leased agricultural land; and (in EU-12) for labour and land productivity and machinery and equipment value.

Table 2. Correlation between the cost of services use and the value of selected variables referring to agricultural farms specialized in horticulture in EU-12 in 2000-2016

\begin{tabular}{|c|c|c|c|c|c|}
\hline Specification & Agricultural & $\begin{array}{c}\text { Agricultural } \\
\text { services } \\
\text { services } \\
\text { per farm } \\
\text { agricultural } \\
\text { land }\end{array}$ & $\begin{array}{c}\text { Agricultural } \\
\text { services } \\
\text { per AWU }\end{array}$ & $\begin{array}{c}\text { Share of } \\
\text { agricultural } \\
\text { services in } \\
\text { total } \\
\text { intermediate } \\
\text { consumption }\end{array}$ & $\begin{array}{c}\text { Service } \\
\text { intensity } \\
\text { rate }\end{array}$ \\
\hline Agricultural services per farm & $\mathbf{X}$ & +++ & +++ & ++ & +++ \\
\hline $\begin{array}{c}\text { Agricultural services per ha of } \\
\text { agricultural land }\end{array}$ & ++ & $\mathbf{X}$ & +++ & +++ & +++ \\
\hline Agricultural services per AWU & +++ & +++ & $\mathbf{X}$ & +++ & +++ \\
\hline $\begin{array}{c}\text { Share of agricultural services in } \\
\text { total intermediate consumption }\end{array}$ & ++ & ++ & +++ & $\mathbf{X}$ & +++ \\
\hline Service intensity rate & +++ & +++ & +++ & +++ & $\mathbf{X}$ \\
\hline Land productivity & +++ & +++ & +++ & ++ & ++ \\
\hline Labor productivity & +++ & ++ & +++ & ++ & ++ \\
\hline Rented utilized agricultural area & ++ & - & ++ & + & ++ \\
\hline Unpaid and paid labor input & ++ & + & + & + & + \\
\hline Machinery & +++ & ++ & ++ & ++ & ++ \\
\hline Gross value added & ++ & ++ & ++ & + & ++ \\
\hline
\end{tabular}

a Panel correlation analysis of time series spanning from 2004 to $2016, p<0.05$. The values of variables compared are expressed in constant prices. The values of correlation coefficients are marked as follows: "+" below 0.3 (weak correlation); "++" 0.3-0.7 (moderate correlation); "+++" 0.7-1.0 (strong correlation). Negative correlation is marked as follows in the corresponding intervals: "-", "-- " and "---".

Source: Own study based on FADN Database (2018) 
The service intensity of crop production was correlated the most with the share of service costs in intermediate consumption (which seems quite obvious) and with the service cost per AWU; and (in EU-12) with service costs per farm and per hectare of AL. A slight positive correlation existed for the additional area of leased agricultural land and machinery and equipment value; and (in EU-12) for land and labour productivity and gross value added; and (in EU-7) for service cost per farm and per hectare of AL.

The results indirectly confirm the existence of a relationship between production specialization and intensification, on one side, and an increase in demand for production services, on the other, as described by Olewnicki (2009). Services enable the rationalization of employment and the optimization of physical capital structure, primarily including machinery and equipment. This is especially true for farms who deliver products that are often unfit for storage and require maintaining a sophisticated technological system and the timeliness of cropping, treatment and harvesting operations. The use of proper equipment, plant protection products and fertilizers better tailored to actual agritechnical needs of specialized farms is a way to improve production efficiency and profitability.

Table 3. Correlation between the cost of services use and the value of selected variables referring to agricultural farms specialized in horticulture in EU-7 in 2000-2016 ${ }^{\mathrm{a}}$

\begin{tabular}{|c|c|c|c|c|c|}
\hline Specification & Agricultural & $\begin{array}{c}\text { Agricultural } \\
\text { services } \\
\text { services } \\
\text { per farm } \\
\text { agricultural } \\
\text { land }\end{array}$ & $\begin{array}{c}\text { Agricultural } \\
\text { services } \\
\text { per AWU }\end{array}$ & $\begin{array}{c}\text { Share of } \\
\text { agricultural } \\
\text { services in } \\
\text { total } \\
\text { intermediate } \\
\text { consumption }\end{array}$ & $\begin{array}{c}\text { Service } \\
\text { intensity } \\
\text { rate }\end{array}$ \\
\hline Agricultural services per farm & $\mathbf{X}$ & ++ & +++ & ++ & ++ \\
\hline $\begin{array}{c}\text { Agricultural services per ha of } \\
\text { agricultural land }\end{array}$ & ++ & $\mathbf{X}$ & ++ & ++ & ++ \\
\hline Agricultural services per AWU & +++ & ++ & $\mathbf{X}$ & ++ & +++ \\
\hline $\begin{array}{c}\text { Share of agricultural services in } \\
\text { total intermediate consumption }\end{array}$ & ++ & ++ & ++ & $\mathbf{X}$ & +++ \\
\hline Service intensity rate & ++ & ++ & +++ & +++ & $\mathbf{X}$ \\
\hline Land productivity & + & +++ & + & + & + \\
\hline Labour productivity & ++ & ++ & ++ & + & + \\
\hline Rented utilized agricultural area & +++ & $+/$ & +++ & ++ & ++ \\
\hline Unpaid and paid labour input & ++ & ++ & ++ & + & + \\
\hline Machinery & +++ & + & ++ & + & ++ \\
\hline Gross value added & +++ & ++ & ++ & + & + \\
\hline
\end{tabular}

aExplanations as in table 2

Source: Own study based on FADN Database (2018) 
In addition to the measureable variables covered by the study, the EU institutional regulations can affect the level of agricultural services use by horticultural farms. Regulations related to the quality of food production and promoting sustainable development of agriculture, as well as CAP policy instruments can have a key importance. Aiming to better product quality and sustainability will tend to increase the willingness to use services, while CAP instruments can have a dual effect. They can increase or decrease the propensity to substitute unpaid labour and capital investment by services (see Czyżewski 2016, Kołodziejczak, Poczta 2018).

\section{Conclusion}

The objective of the study was to identify the output of agricultural services used by farms specializing in horticultural crops in European Union countries in 2004-2016. In the group of farms covered by this study, the use of agricultural services may be found to depend on two basic factors.

1) The first one is the farms' development level and the intensity and structure of production activities. A higher cost of agricultural services is characteristic of more developed, modern horticultural holdings engaged in intensive production (EU-12). In the case of horticultural production, modern and intensive production activities mean the need to maintain a sophisticated technological system and to ensure timeliness of cropping, treatment and harvesting operations. However, the differences between EU-12 and EU-7 countries suggest that national specificities of horticultural production and local farming patterns are at least as important as the development level.

2) Another significant factor is the availability of the farms' own machinery and the amount of labour engaged in production. However, own equipment and service use were not found to be substitutes, whereas companies with large resources of productive inputs usually incurred higher service costs. Also, as the demand for labour grows, so does the demand for services. This suggests that services are complementary rather than substitute to physical capital.

3) In addition to the measureable variables covered by the study, the EU institutional regulations, including those related to the quality of food production and promoting sustainable development of agriculture can affect the level of agricultural services use by horticultural farms. On the other hand, CAP policy instruments can decrease or increase the level of services use.

\section{Reference}

BELL, D. (1989). Die nachindustrielle Gesellschaft. Campus Verlag Frankfurt/New York, pp. (in Germany).

CORSTEN, H. (1990). Betriebswirtschaftslehre der Dienstleistungsunternehmungen. R. Oldenbourg Verlag München Wien.

CZYŻEWSKI B. (2016). Kierat rynkowy w europejskim rolnictwie. Wyd. PWN, Warszawa 
DASZKOWSKA, M. (1998). Usługi. Produkcja, rynek, marketing. Wyd. Nauk. PWN, Warszawa.

FADN Database (2018). Retrieved from: http://ec.europa.eu/agriculture/rica/database/database_en.cfm, accessed on May 24, 2018.

FLEJTERSKI, S., KLÓSKA, R., MAJCHRZAK, M. (2012). Usługi w teorii ekonomii, In: Flejterski, S., Panasiuk, A., Perenc, J., Rosa G. (Eds.), Współczesna ekonomika usług. Wyd. Nauk. PWN, Warszawa pp.13-40.

HAMM, R. (2012). Verbund von Industrie und Dienstleistungen wird enger. Wirtschaftsdienst 9, ZBW Leibniz-Informationszentrum Wirtschaft.

HÄUSSERMANN, H., SIEBEL, W. (2011). Theorien der Dienstleistungsdesellschaft. In: Evers, A., Heinze, R. G., Olk, T. (Eds.), Handbuch Soziale Dienste. VS Verlag für Sozialwissenschaften Springer Fachmedien Wiesbaden, pp. 62-75.

JENSEN, J. B. (2011). Global Trade in Services: Fear, Facts, and Offshoring. Washington, DC, Peterson Institute for International Economics Press.

JÓZWIAK, W. (1998). Techniki wytwórcze w agrobiznesie. In: Woś, A. (Eds.), Encyklopedia Agrobiznesu. Fundacja Innowacja, Warszawa, pp. 882-884.

KARWAT-WOŹNIAK, B. (2008). Zmiany $w$ sytuacji ekonomicznej rodzinnych gospodarstw wysokotowarowych. Raport Programu Wieloletniego 2005-2009 nr 111, IERiGŻ-PIB, Warszawa.

KOŁODZIEJCZAK, M. (2016). Assessment of the use of services in agriculture of the EU countries based on input-output tables. Proceedings of the 2018 International Conference "Economic Science for Rural Development" No 47, Jelgava, LLU ESAF, 9-11 May 2018, pp. 149-155, DOI 10.22616/ESRD.2018.000

KOŁODZIEJCZAK, M., POCZTA, W. (2018). Changes in the use of production services in agriculture in the context of meeting the targets of sustainable agricultural development. Proceedings of the 2018 International Conference „Determinanty rozwoju regionalnego. Rozwój zrównoważony - od perspektywy regionalnej od polityki Unii Europejskiej”, Piła, 17-18 March 2018 (In print).

KOWALCZYK, S. (1983). Organizacja usług produkcyjnych dla rolnictwa w wybranych krajach. Ośrodek Informacji Centralnej - CINTE, Warszawa.

OLEWNICKI, D. (2009). Rozwój usług dla gospodarstw ogrodniczych w latach 2001-2006. Zeszyty Naukowe SGGW Ekonomika i Organizacja Gospodarki Żywnościowej nr 73, pp. 155-163.

POCZTA, W. (1994). Rolnictwo polskie a rolnictwo EWG (studium komparatywne). Roczniki AR w Poznaniu, Poznań.

Regulation (EC) No 138/2004 of the European Parliament and of the council of 5 December 2003 on the economic accounts for agriculture in the Community (Text with EEA relevance). Official Journal $L$ $033,05 / 02 / 2004$, pp.1-87. 